\title{
Forest Policies and Forest Fringe Households' Resilience against Poverty in Participatory Forest Management Sites in Burkina Faso
}

\author{
Boukary Ouedraogo \\ Centre d'Etudes, de Documentation et de Recherche Economique et Social (CEDRES) \\ Université Ouaga2, 04 BP 8938 Ouagadougou 04, Burkina Faso \\ Tel: 226-78828132Ｅ-mail : b.ouedraogo@univ-ouaga2.bf
}

Received: October 20, 2017 Accepted: January 5, 2018

doi:10.5296/emsd.v7i1.12523 URL: https://doi.org/10.5296/emsd.v7i1.12523

\begin{abstract}
This paper uses an original dataset that was built upon extensive surveys covering 300 forest fringe households on the main participatory forest management (PFM) sites in Burkina Faso. We then combine simultaneously the seminal approach of Foster, Greer and Thorbecke (1984) monetary poverty indices and the Béné's (2013) approach of resilience on costs (expenditures) analysis, so as to emphasize forests fringe households' resilience against poverty mainly by capturing the induced changes by the 1998 forest policy, in these households' abilities to cope with poverty. The major outcomes are: (i) forest income sources remain the most dominant in households' total income for 1997 and 2004; (ii) both poverty rate and poverty gap decrease from 1997 to 2004 . This decline in the level of poverty is mainly explained by the households' coping strategies through the development of investments and others expenditures (agricultural equipment, livestock, poultry, trade, crafts activities and processing of NTFPs) so that to cope with poverty; (iii) forest fringe households are resilient against poverty in PFM sites. The main environmental policy implication of this study should be to update the levels of the instruments of the environmental policy (forest), twenty years after the implementation of the 1998 forest policy so that to reinforce forest households' resilience and forest sustainability.
\end{abstract}

Keywords: Participatory forest management, Forest policy, Resilience, Poverty, Forest fringe households, Forest sustainability, Forest incomes 


\section{Introduction}

Natural resource management is a system of controlling the use of resources to avoid wastage and maximize the use of resources in order to obtain the best possible benefit and forest sustainability (Collins, 1992). Forest policies in Burkina Faso today, are characterized by new socio-cultural approaches based on the active and voluntary participation of local populations as a central factor in starting a sustained exploitation of these resources. Since 1983, the national policy of forest management has refocused on the role of local people in the planning and the management of forest resources. This participatory forest management (PFM) approach was set up in 1986 in the form of a pilot project called "Natural Forest Management" aimed at supplying people with wood energy and safeguarding the environment (Kabore, 2004). In that project, the producer price was regulated in all PFM sites by central forest authorities.

Forest is an important source of incomes and allows livelihood diversification to forest fringe households mainly through the exploitation of timber and non-timber forest products (Ouedraogo, 2009; Babulo et al., 2009; Das, 2010). Many studies highlight that natural forests provide to African rural and urban people for food, energy, medicine, animal feed, construction, furniture, agricultural implements and utensils while providing ecological services (Mamo et al., 2007; Shackleton et al., 2007; Coulibaly-Lingani et al., 2009). Many other authors emphasize that forests offer a large potential for poverty alleviation among forest dependent households (Yao, 1999; Wunder, 2001; Kumar et al., 2000; Kumar, 2002; Ouedraogo et Ferrari, 2015). Authors like Ribot (1995), Foley et al. (1997, 2002), Hautdidier et al. (2004), Atchoumgaï (2003) and Ouédraogo (2002, 2007) have already investigated in the rural markets of fuelwood and the control of local forests in Sub-Saharan Africa and more particularly in Burkina Faso, Mali and Niger. These authors questioned the effects of PFM on loggers, and how these reforms have benefited economically and socially these local producers (Hautdidier \& Gautier, 2005).

These studies which highlight the importance of forest revenues for poverty alleviation, say little about how forest policies and fringe forest households' forest income use could reflect their ability to adapt and combat poverty, that is, their resilience against poverty. "Resilience is the ability of a system, community, or society potentially exposed to hazards to adapt, by opposing resistance, or by amending, in order to achieve or continue to function properly, with acceptable structures. The resilience of a social system is determined by the ability of the system to organize itself so that it is better able to learn from past disasters to better protect itself and to reduce risks more effectively (UNISDR, 2005). The World Development Report (World Bank, 2013) and the Human Development Report (UNDP, 2014) mobilize the notion of resilience, which is now "seen as a new, highly innovative tool for fight against poverty, hunger and "disasters". It is especially with the 2005-2015 Hyogo Framework for Action, "for Disaster Resilient Nations and Communities" (UNISDR, 2005), a framework adopted by 168 countries, that claims to install a new "culture" as expressed in its third priority of action: "using knowledge, innovations and education to build a culture of security and resilience at all levels", as this notion has been gaining momentum, particularly with the recurrence of natural disasters such as the Asian Tsunami in December 2004, Hurricane 
Katrina in August 2005, and the earthquake in Haiti in December 2010. Indeed, Lallau (2014) highlights the relevance of this notion to assess the resilience of households against hunger and food insecurity. Lind, Sabates-Wheeler and Kohnstamm (2016) investigated the mapping of livelihood dynamics and resilience within pastoralist systems in Drylands East Africa. Cantoni et Lallau (2010) use the notion of resilience to study the dynamics of adaptation of Kenyan pastoral community that faces to climate change and political uncertainties.

Regarding the approaches developed in the field of ecology (Folke et al., 2002) and applied to development studies (Béné et al 2012; Frankenberger et al, 2014), the resilience construct is considered to represent three types of capacity to respond to shocks and stressors: i) the ability to absorb shocks and stressors, ii) the ability to adapt to shocks and stressors, and iii) the ability to respond to shocks and stressors. It may therefore be useful to know how different capacities contribute to the ability to absorb, adapt or transform into shocks.

This paper more particularly aims at studying how public forests' policies contribute to forests fringe households' resilience against poverty. The study does so address two main issues: (i) How forest policies in Burkina Faso strengthen forest fringe households' resilience of against poverty? (ii) Do forest fringe households resilient against poverty in participatory forests' management sites of Burkina Faso?

Using an original dataset that was built upon extensive surveys covering forest fringe households on the main participatory forest management (PFM) sites in Burkina Faso on the topic "Effects of PFM on forest fringe households' welfare in Burkina", we use the seminal approach of Foster, Greer and Thorbecke (1984) poverty indices so as to analyse poverty reduction in this paper. The Béné (2013) ex-ante and ex-post approach of resilience on costs (expenditures) analysis is used and so applied to poverty indices.

The section 2 of this paper presents the specific context of forest policies and participatory forest management in Burkina Faso. Section 3 deals with the theoretical framework of the study while section 4 presents the dataset used. Section 5 presents the empirical results on the resilience's profile of forest fringe households in PFM sites in Burkina. Section 6 concludes.

\section{Specific Context of Forest Policies and Participatory Forest Management in Burkina}

The PFM program in Burkina Faso currently spans over 10 provinces and covers more than 667600 hectares of forest protected areas. Table 1 below gives the main PFM sites providing Ouagadougou in wood-energy, which will constitute the main perimeter of our study.

In PFM sites, the local partners (the forest fringe households) are organized into Village Forest Management Groups (VFMGs) trained in forestry, which are responsible for the forest resources management and for the promotion of local development. These VFMGs are associative or cooperative groups. They are also responsible for the protection of Forest Management Units (FMU) against any form of occupation which does not comply with forestry rules and with forest resources sustainability. For increasing credibility, VFMGs have set up umbrella organizations called Unions of Village Forest Management Groups (UVFMGs). The State remains the owner of the land and allows to UVFMGs the autonomy in the management of the forest areas that are recorded according to a specific categorization. 
Table 1. Characteristics of selected managed forest areas

\begin{tabular}{|l|r|r|l|r|r|r|r|}
\hline Forest Lands PFM & $\begin{array}{l}\text { Forest } \\
\text { land (ha) }\end{array}$ & $\begin{array}{l}\text { Start } \\
\text { Dates }\end{array}$ & $\begin{array}{l}\text { Average } \\
\text { prod./year } \\
\text { (steres) }\end{array}$ & $\begin{array}{l}\text { Number } \\
\text { of } \\
\text { VFMG }\end{array}$ & $\begin{array}{l}\text { Number } \\
\text { of } \\
\text { members }\end{array}$ & $\begin{array}{l}\text { Distance } \\
\text { from capital } \\
\text { city }\end{array}$ & Statute \\
\hline Bougnounou & 24914 & 1993 & 12000 & 30 & 1860 & 135 & Autonomous \\
\hline Cassou & 29515 & 1990 & 23000 & 24 & 960 & 150 & Autonomous \\
\hline Nakambé & 21424 & 1998 & 17000 & 20 & 336 & 45 & Autonomous \\
\hline Nazinon & 24899 & 1987 & 51000 & 30 & 919 & 70 & Autonomous \\
\hline Sapouy-Biéha & 21000 & 1996 & 54850 & 31 & 937 & 100 & Autonomous \\
\hline Silly-Pouni-Zawara & 52000 & 1993 & 58933 & 50 & 1706 & 125 & Autonomous \\
\hline South-West Sissili & 55964 & 2001 & 58930 & 55 & 1100 & 165 & Autonomous \\
\hline Total/Average $(*)$ & $\mathbf{2 2 9} 717$ & & $\mathbf{3 9 3 8 7 . 5 7}(*)$ & $\mathbf{2 4 0}$ & $\mathbf{7 8 1 8}$ & $\mathbf{1 1 2 . 8 6}(*)$ & \\
\hline
\end{tabular}

Source: CIFOR-Burkina Forestry Surveys (2005), Ministry of Environment (2004)

Around 50\% of those managed forest areas are autonomous and run by more than 10 UVFMGs officially recognized which, in turn, group more than 400 VFMGs. By the way, the different UVFMGs are grouped in a national federation of unions which rules on forest management guidelines for forest management at the level of the whole country. Those 7 PFM sites cover 230000 hectares with an average annual timber production of 39387.57 steres. A total of 240 VFMGs working in those forest managed areas, count altogether 8000 members. The average distance of these PFM sites from Ouagadougou is $113 \mathrm{~km}$.

Logging in PFM sites has been done with respect to forestry standards. Loggers are trained in forestry techniques, including cutting techniques, and are surrounded by a forest engineer named Technical Director who provides technical management of sustainable use of the forest. The adopted management model is participatory that can be considered as a partnership where two or more parties negotiate together, agree and execute functions, benefits and responsibilities associated with a particular territory or set of natural resources (Gray, 1998). Thus, the PFM of the protected forest areas contributes to the maintenance of the ecosystem and its wildlife. It also aims at guaranteeing the welfare of local people via legal and institutional mechanisms as well as an equal partnership between these communities and government agencies (Kothari et al., 1996).

This forest management project was initially funded by the United Nations Development Programme (UNDP), the World Bank, the French Development Fund (AFD) and the bilateral cooperation with Norway in1980s and 1990s and have raised more than 20 billion CFA francs (Ouedraogo, 2002). Today, and notably in the case of sample we cover in our study, most of the sites have become autonomous and coordinated by Village Forest Management Groups. On the other hand, their activity is now fully funded by the forest tax and forest management fund (FMF) (see table 2 below) together with government technical support.

This option of forest management programs in Burkina Faso, is based on the following ideas: (i) if forest riparian populations are formed, empowered, organized and technically supervised by the public services of the environment, then if these populations benefit from forest management, they could appropriate and take over the management of these forest areas autonomously, efficiently and sustainably; (ii) forest management requires financing, and the sustainability of these programs necessarily means self-financing of these programs 
and a constant improvement of the working conditions of the loggers and the villages concerned. This is why, since the 1990s, the State has implemented a new price structure for the fuelwood producer and has instituted appropriate economic instruments for environmental policies. However, there was a need to constantly review the remuneration of loggers, to take into account inflation and persistent poverty in rural Burkina Faso.

Table 2 shows changes in forest policy instruments through the new fuelwood producer's price structure. This is the case for loggers' remuneration (LR) and for Forest Management Fund (FMF), which respectively rose from 610 FCFA and 500 FCFA per stere to 1,100 FCFA and 600 FCFA per stere. Producer prices are administered upstream of this controlled fuelwood sector. Thus, the price to the producer or to wholesaler goes from 1,610 FCFA per stere in 1996 to 2,200 FCFA per stere in 1998. The increase in the remuneration of the loggers, while restoring the rent position, created a greater incentive for local populations of PFM sites.

Table 2. Changes in the producers' price structure in PFM sites $(1995,1998)$

\begin{tabular}{|c|c|c|c|c|}
\hline Sections & $\begin{array}{c}\text { Year } 1995 \\
(\text { FCFA/stere) }\end{array}$ & $\begin{array}{c}\text { Year } 1998 \\
(\text { FCFA/stere) }\end{array}$ & $\begin{array}{c}\text { Variation } \\
(\mathrm{FCFA} / \text { stere })\end{array}$ & $\begin{array}{c}\text { Variation } \\
(\%)\end{array}$ \\
\hline Forest Tax (FT) & 300 & 300 & 0 & 0.00 \\
\hline $\begin{array}{lll}\text { Forest } & \text { Management Fund } \\
(\mathrm{FMF}) & & \\
\end{array}$ & 500 & 600 & 100 & 20.00 \\
\hline $\begin{array}{lll}\begin{array}{l}\text { Village } \\
\text { (VRF) }\end{array} & \text { Revolving } & \text { Fund } \\
\end{array}$ & 200 & 200 & 0 & 0.00 \\
\hline Loggers' remuneration (LR) & 610 & 1,100 & 490 & 80.33 \\
\hline Stere price in FCFA & 1,610 & 2,200 & 390 & 36.65 \\
\hline
\end{tabular}

Source: PNUD/BKF/93/003 (1999)

Thus, forest tax and forest management funds(FMF) accounted for $41 \%$ of fuelwood's producer price so that when forest revenues are low: (i) the need for forest exploitation is higher, which in turns may harm the forest, and (ii) the capacity to invest in new "and green" technologies are also low, which is not good for the future forest revenues. The FMF is mainly used for forest management purposes (Ouédraogo, 2007). Thus, the increase of the FMF in 1998 aims to strengthen forests' management and sustainability. The village revolving fund (FRF) also called Village investment fund, amounting to 200 FCFA per stere cut and sold in the PFM sites, aims at improving the collective village's welfare (to create and / or maintain social infrastructures such as schools, drilling and dispensaries, etc ...).

\section{The Theoretical Framework}

The theoretical basis of this study is focused on the poverty' monetary approach and the integration of the notion of resilience to understand the strategies developed by forest households to cope with poverty. The idea being that the forest policy implemented in 1998 by the public authorities aimed simultaneously at safeguarding the environment, providing fuelwood to rural and urban peoples while improving the living conditions of forest households, has positively impacted the riparian households' income. It is therefore appropriate to link the impact of this policy to the adjustment behaviours developed by these households to cope with poverty. The concepts of poverty and resilience should be clarified, 
suitable methods should be proposed to evaluate them, and a coherent relationship established between them.

Among the institutional definitions that have been developed on the notion of resilience, we will retain that of USAID which seems to cover and contain the others: "Resilience is the ability of people, households, communities, countries, and systems to mitigate, adapt to, and recover from shocks and stresses in a manner that reduces chronic vulnerability and facilitates inclusive growth." (USAID, 2012). So, Resilience is conceived as a tool for integrating the fight against poverty, climate adaptation, and disaster preparedness; thus, the regions of the world concentrating these various evils constitute priority experimental areas for policies and programs that claim to be the same. Among these are the vulnerable coastal areas of South Asia, the countries of the Horn of Africa, or the Sahel region of Sub-Saharan Africa. Among the flagship initiatives is SHARE (Supporting the Horn of Africa's Resilience) and AGIR, the Global Alliance for the Resilience Initiative, initiated in the Sahelian zone by the European Union (AGIR, 2013), or the plan " Zero Hunger" launched in 2013 by West African leaders. For Lallau (2014), one of the elements of context that will foster the emergence of resilience, lies in the "poverty reduction strategies». The Millennium Development Goals (MDGs) guide these strategies, and highlight the multidimensionality of poverty, as hunger cannot be dissociated from other characteristics of a poor person's life.

In this section, we respectively deal with the methods of households' resilience assessment (2.1.) and the methods of poverty assessment (2.2.).

\subsection{Methods of Households' Resilience Assessment}

The essential methodological elements that result from the above literature review are the need for a dynamic approach that captures the resilience of households to a shock, hence the relevance of identifying a change of situations relating to the reaction of households following this shock. The main shock induced by forest policy is the changes in the fuelwood producer's price structure in 1998, which increases the loggers' remuneration and the forest management fund. Also, the reference's dates are 1997 and 2004; year 1997, because it is the year before the implementation of this pricing policy; and 2004, since the May-June 2005 surveys took into account the data for the year 2004.

Several approaches have been developed to assess resilience such as Keil et al. (2008) who used a single proxy approach, Barrett \& Constas (2012) who expressed resilience in terms of probability, while Béné (2013) proposed a cost analysis of resilience which may lead to an independent measurement of the explanatory variables. For Béné (2013): "the 'cost of resilience' (that is, the ex-ante difference and ex-post investments, losses, sacrifices, and costs that people have to incur individual and collective levels to "go through" a shock or an adverse event. Béné (2013) has grouped into three categories these costs: (i) the ex-ante investments made as preparedness process (anticipation costs); (ii) the costs of destruction following the impact of the shock; and (iii) the ex-post costs of recovery, including the replacement costs of what has been destroyed but also the various costs associated with change/adaptation, or transformation and the cash/food/assets transfers that are implemented through ex-post emergency/assistance interventions. In our paper, we'll mainly deal with the 
third one that focuses on the induced changes in households' expenditures by the 1998 forest policy in PFM sites in Burkina, so that to capture their coping strategies with poverty.

For Lallau (2014), the assessment of resilience means providing clear answers to the following questions: From whom? Compared to what? What? When? And above all, how? From whom, first of all. Treating simultaneously different scales and their interactions contributes to the difficulty of operationalizing the notion. We can then retain only one scale. Choosing forest fringe households in our case study can be fully justified when dealing with the issue of poverty, because it is often the one that is favoured by humanitarian workers and donors to assess the needs of the population and the impacts of the programs implemented. Resilience can then be defined as a household's ability to cope with adversity (Lallau \& Droy, 2014).

To the question "Compared to what?", we focus our attention on forest fringe households' poverty in PFM sites. About "What?", the implemented forest policy occurred in 1998 through the adoption of a new fuelwood producer's price structure is considered as a shock that could affect these households' welfare and develop among them behaviours that can help them adapt to poverty. Answering to the question "when", we propose the ex-ante and ex-post approach, ie 1997 (the year preceding the occurrence of the policy in 1998) and the year preceding the date of the surveys or evaluation year 2004 (2005 for surveys' year). That's why we have made the following assumptions:

1- The change in the fuelwood producers' price structure in 1998 has allowed increasing the forest management fund, which improves the financing of forest management programs that support forests' sustainability.

2- The change in the fuelwood producer's price structure in 1998, which has led to an $80.33 \%$ increase in loggers' remuneration, is a motivation that will lead to better participation in participatory management of forests' activities and thus, to a greater sustainability of forests in PFM sites.

3- The change in fuelwood producer's price structure in 1998, which led to an $80.33 \%$ increase in loggers' remuneration, will lead to a better allocation of this income, particularly in their agricultural and livestock practices, education and health; all things that will increase their future incomes and therefore their resilience to poverty. From this perspective, forest revenues have a significant impact on poverty reduction.

Therefore, the approach of Béné (2013) that highlights the analysis of the difference between ex-ante and ex-post by the costs (expenditures) developed by individuals or communities to cope with poverty seemed to us the most appropriate approach for our study.

Figure 1 below provides a modelling sketch of the links between forest policies and sustainability and households' resilience against poverty.

This figure relates the instruments of forest policy, the beneficiaries of this policy, the main adjustment variables of forest households (their income, savings and expenditures) and its implications for these households' resilience to poverty (resilience outputs). 


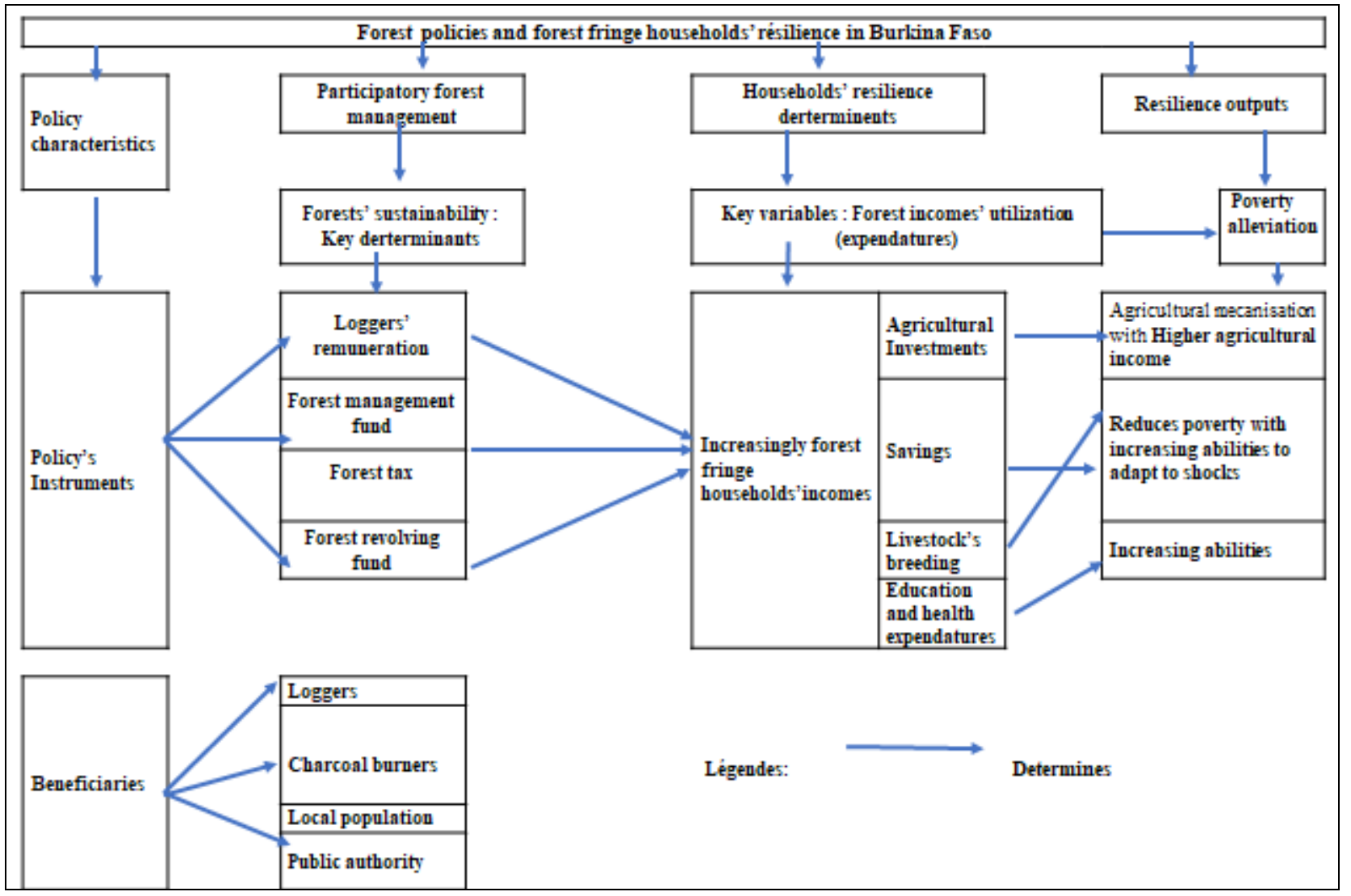

Figure 1. Modelling the links between forest policies, forest sustainability and households' resilience against poverty

\subsection{Methods of Poverty Assessment}

We adopt the widely used formula developed by Foster-Greer-Thorbecke (FGT) (1984) to calculate monetary poverty indices in order to assess the state and changes in poverty among forest fringe households. The poverty line that is an input in the FGT formula, is defined as the minimum income level which would be required to allow any individual of a given society to survive (INSD, 2000). In this case, the poverty line is a normative level of expenditure below which people are considered to be poor. The (related) absolute poverty lines are equal respectively to 41099 FCFA per capita per year (INSD, 1996), 72690 FCFA per capita per year (INSD, 2000) and 82672 FCFA per person per year (INSD, 2003).

The main indices making up the FGT family are the poverty rate, the poverty gap (depth) and the poverty severity. We can compute them through the following formula:

$$
P_{\alpha}\left(Z, Y_{i}\right)=\frac{1}{n} \sum_{1}^{q}\left(\frac{Z-Y_{i}}{Z}\right)^{\alpha}
$$

Where $\alpha$ refers to the "diversion" for poverty (i.e. a parameter representing the importance placed on the welfare of the poorest of the poor); $\mathrm{Z}$ to the national poverty line (we chose to set it as 82672 FCFA per person and per year (see IND (2003)), $Y_{i}$ the $\mathrm{i}^{\text {th }}$ individual income and $\mathrm{q}$ the number of poor people (i.e. those for which $Y_{i}$ is less than $\mathrm{Z}$ ) and the $\mathrm{n}$ the whole 
population size. In that formula, individuals are supposed to be ranked in ascending order, from the poorest $(i=1)$ to richest $(i=n) \alpha$. The poverty rate $\left(P_{0}\right)$, the poverty gap $\left(P_{1}\right)$ and the poverty severity rate $\left(\mathrm{P}_{2}\right)$ are computed respectively by replacing $\alpha$ in Equation (4) by respectively 0,1 and 2 .

\section{Dataset of the Study}

The data used in this paper have been collected through large surveys implemented by the International Centre for Forestry Research (CIFOR) in May-June 2005 on the main PFM sites in Burkina Faso and funded by USAID. These surveys initially aimed at assessing "The effects of forest policies on local populations' life conditions", mainly on forest fringe households' welfare.

Table 3. Distribution of household's characteristics by PFM site

\begin{tabular}{|l|c|c|c|c|c|c|c|}
\hline \multirow{2}{*}{ PFM sites } & \multirow{2}{*}{ Household size } & \multirow{2}{*}{ Average Age } & \multicolumn{2}{|c|}{ Gender $(\%)$} & \multicolumn{4}{|c|}{ Education (\%) } \\
\cline { 4 - 9 } & & & Female & Male & No formal & Primary & Secondary \\
\hline Cassou & 7 & 35 & 0 & 100 & 36 & 59 & 5 \\
\hline Silly-Pouni-Zawara & 10 & 38 & 5 & 95 & 84 & 13 & 2 \\
\hline South-West Sissili & 5 & 36 & 0 & 100 & 79 & 21 & 0 \\
\hline Sapoui Bieha & 8 & 37 & 0 & 100 & 70 & 20 & 9 \\
\hline Nazinon & 7 & 41 & 0 & 100 & 93 & 7 & 0 \\
\hline Nakambé & 5 & 29 & 0 & 100 & 81 & 13 & 6 \\
\hline Bougnounou & 7 & 33 & 32 & 68 & 85 & 3 & 13 \\
\hline Mean value/Total & $\mathbf{7}$ & $\mathbf{3 6}$ & $\mathbf{5}$ & $\mathbf{9 5}$ & $\mathbf{7 6}$ & $\mathbf{1 9}$ & $\mathbf{5}$ \\
\hline
\end{tabular}

Source: Analysis of survey data (May-June 2005)

Those surveys covered 23 villages located between $45 \mathrm{~km}$ and $250 \mathrm{~km}$ from Ouagadougou, the country's capital city. On the whole, 300 forest fringe households have been surveyed. The members of these households are mainly woodcutters, charcoal burners who also are non-timber forest producers, farmers. Table 3 above draws the distribution of the socioeconomic characteristics of the households under concern by PFM sites.

The main variables that are captured by these surveys refer to (for each household surveyed):

- The socioeconomic characteristics of the head the household (logger) (age, gender, education, ethnic groups, main and secondary activity...);

- The household income sources (coming either from TFPs and/or NTFPs) and/or from farm income ex-ante and ex-post of 1998, date of the forest policy implementation;

-The changes in households' expenditures structure (investments, education, health, livestock practices, agricultural practices, savings, etc...) ex-ante and ex-post of 1998, are induced by forest policy through the adoption of a new producers' fuelwood price structure in 1998 that is considered as a shock set up by policy makers to improve the forest households living conditions and lead to a greater forests' sustainability.

Through these surveys, which collected forest fringe households' data in the concerned PFM areas for 1997 and 2004, we will be able to examine respectively the induced changes of above mentioned variables by scrutinizing particularly the use of the loggers' incomes, i.e., 
their expenditures (agricultural investments, animal husbandry, areas cultivated, crafts' activities) and on others expenditures such as health, child rearing, pecuniary projects, etc.) that reflect their coping strategies with poverty. Estimating and comparing ex-ante and ex-post (for 1997 and2004) loggers' poverty indicators, allows capturing induced changes in poverty level in PFM sites.

\section{Results: the Resilience's Profile of Forest Fringe Households in PFM in Burkina}

In this part which presents the empirical results of this paper, we deal first with changes induced by the forest policy in the households' income and expenditures structures ex-ante (1997) and ex-post (2004), 1998 being the date of implementation of this policy (4.1.); secondly, we make an empirical investigation on households' resilience face to poverty (4.2.).

\subsection{Changes in Households' Income and Expenditures Structures: a Descriptive Analysis of Their Resilience}

This section focuses respectively on a descriptive analyse of the induced changes in households' income structure (4.1.1.) and the induced changes of households' expenditures structure (4.1.2.).

\subsubsection{Induced Changes in Households' Income Structure}

We more particularly exploit the data on the household income sources, mainly induced changes in households' income from 1997 to 2004. Table 4 gives induced changes by forest policy (1998) in the total income decomposition by type of activity and for the different PFM sites.

Table 4. Household's incomes' structure Changes in PFM sites in Burkina (FCFA ${ }^{1}$ )

\begin{tabular}{|c|c|c|c|c|c|c|c|c|}
\hline \multirow{3}{*}{ PFM sites } & \multicolumn{4}{|c|}{1997} & \multicolumn{4}{|c|}{2004} \\
\hline & \multicolumn{2}{|c|}{ Forest income } & \multirow{2}{*}{$\begin{array}{c}\text { Farm } \\
\text { income }\end{array}$} & \multirow{2}{*}{$\begin{array}{c}\text { Total } \\
\text { income }\end{array}$} & \multicolumn{2}{|c|}{ Forest income } & \multirow{2}{*}{$\begin{array}{c}\text { Farm } \\
\text { income }\end{array}$} & \multirow{2}{*}{$\begin{array}{c}\text { Total } \\
\text { income }\end{array}$} \\
\hline & TFPs & NTFPs & & & TFPs & NTFPs & & \\
\hline Cassou & 744,049 & 284,716 & 473,649 & $1,502,415$ & $1,159,000$ & 443,500 & 737,800 & $2,340,300$ \\
\hline Silly-Pouni-Zawara & $7,483,506$ & 691 & 248,000 & $8,995,198$ & 11657 & 10,750 & $1,944,000$ & $14,011,750$ \\
\hline $\begin{array}{l}\text { South - } \\
\text { West Sissili }\end{array}$ & $6,586,667$ & 730,889 & 3,392840 & $10,710,395$ & $10,260,000$ & $1,138,500$ & $5,285,000$ & $16,683,500$ \\
\hline Sapoui Bieha & $4,598,405$ & 465,560 & & $5,063,965$ & $7,162,900$ & 725,200 & & $7,888,100$ \\
\hline Nazinon & 323,556 & 30,815 & 59,704 & 414,074 & 504,000 & 48,000 & 93,000 & 645,000 \\
\hline Nakambé & $3,072,494$ & & 28,889 & $3,101,383$ & $4,786,000$ & & 45,000 & $4,831,000$ \\
\hline Bougnounol & $2,195,556$ & 82,173 & 89,877 & $2,367,605$ & $3,420,000$ & 128,000 & 140,000 & $3,688,000$ \\
\hline $\begin{array}{l}\text { Average per } \\
\text { household }\end{array}$ & 83,710 & 2 & 23 & 905 & 395 & 9,6 & 395 & 404 \\
\hline Average (\%) & 83 & 6 & 11 & 100 & 78 & 6 & 16 & 100 \\
\hline Total & $25,004,232$ & $1,857,844$ & $5,292,958$ & $32,155,035$ & $38,948,900$ & $2,893,950$ & $8,244,800$ & $50,087,650$ \\
\hline
\end{tabular}

Source: Descriptive Analysis of survey data (CIFOR/May-June 2005)

The forest fringe households' aggregate income is decomposed in three sources regarding their main activities namely forest income (non-timber forest products (NTFPs) and timber forest products (TFPs)) and non-forest income (farm). Forest source of income comes from

1 FCFA $=$ Monetary Unit of African Financial Community 1 Euro $=655.957$ FCFA 


\section{Ml Macrothink}

Environmental Management and Sustainable Development

ISSN 2164-7682

2018, Vol. 7, No. 1

the sale of timber products (firewood and charcoal) and from the sale of NTFPs like wild fruits (pulp Shea, almond Shea, grape, honey, etc.). Non-forest earnings concern farm income - arise from the sale of agricultural products, from farm crops, from non-forest wage labour (mainly coming from agricultural farm labour) or from other revenues (self-employed business activities). The average per household total income goes from 100,905 FCFA in 1997 to 166,404 FCFA in 2004, all activities together, while total income in all PFM sites goes from 32,155,035 FCFA to 50,087,650 FCFA for the same period.

Figure 2 illustrates that average income per household mainly comes from timber forest activity (that represented 84\% in 1997 and $78 \%$ in 2004 of total average income/household), most of which being wood harvesting and, to a lesser extent, when prevailing, charcoal burning; then farming, while the collection of NTFPs (remain the same for 1997 and 2004 of $6 \%$ of total average income/household) does only marginally contributes to the aggregate income of forest fringe households. From 1997 to 2004, the average farm income per household increases from $11 \%$ to $16 \%$.

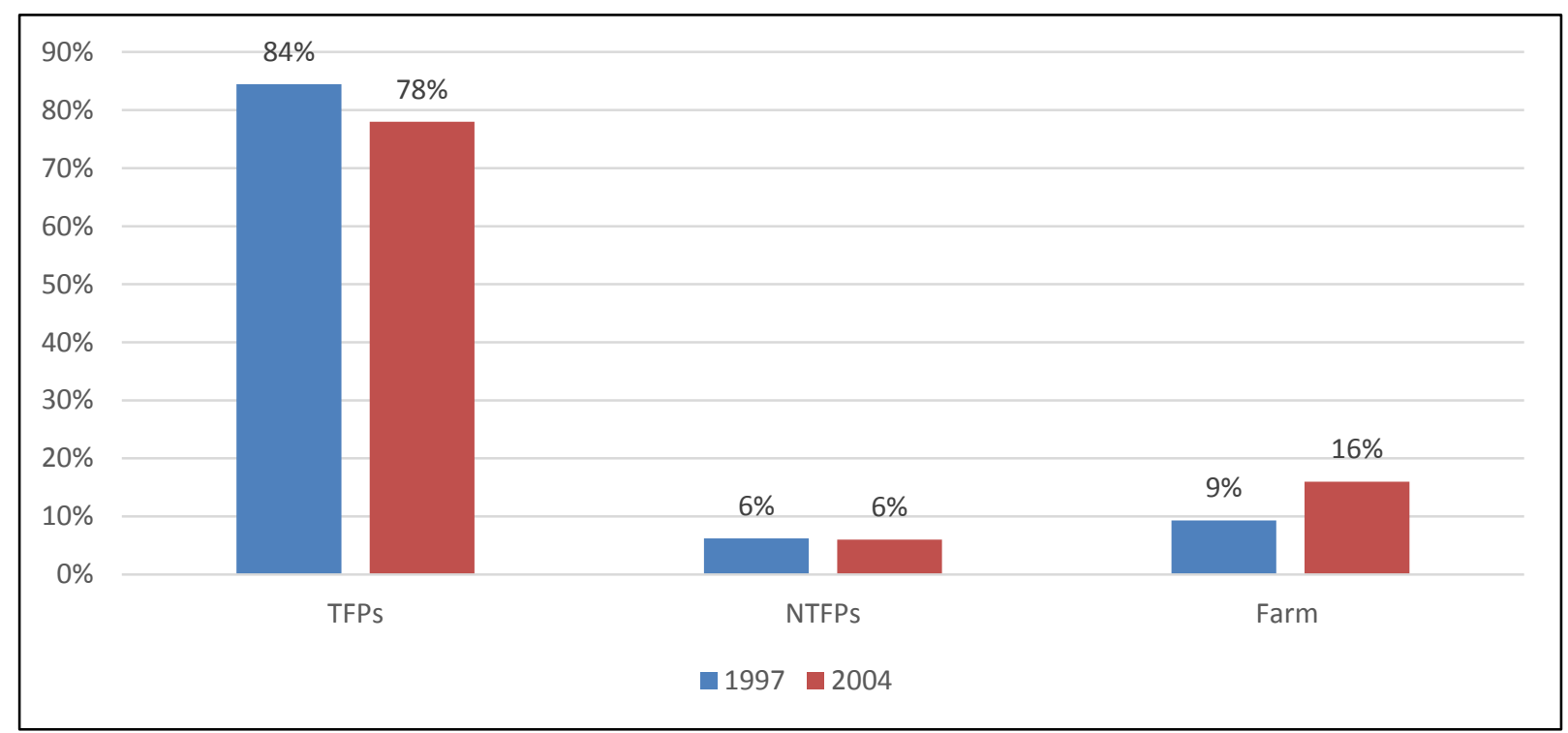

Figure 2. Changes in forest fringe housholds' income structure in PFM areas

What is remarkable is the consecutive decline in the share of the average TFPs income per household and the consecutive increase in the share of the average farm income per household. As a result, we assume that these changes in averages TFPs income and farm income per household is the result of households' coping strategies that used their additional income from the 1998 forest policy to invest in agricultural and livestock activities; which allowed an increase in their agricultural and livestock incomes in 2004 compared to those of 1997. Besides this average decomposition, we can observe a wide spatial dispersion in the average income of households across the PFM sites: the overall standard deviation of average total gives a coefficient of variation close to $179.30 \%$ among the PFM sites.

As suggested (Ouedraogo, 2009), this disparity can probably be explained in the first place by the differences that we can observe between the PFM sites with respect to their agro-climatic conditions as the latter entail different economic opportunities for the timber and non-timber 
forest activities as well as farming.

To summarise, the empirical evidence obtained for the PFM sites reveals that forest fringe households which participate in PFM in Burkina are dependent on timber forest activity. This situation is very common in other developing countries. According to Reddy and Chakravarty (1999, page 1142): "The households' dependence on forests in the North region in India is for fuelwood, fodder and auxiliary NTFPs, with the major proportion of dependence contributed by fuelwood and fodder." Otherwise, the increase in loggers' remuneration in 1998 allows a better opportunity to these households to cope with poverty by investing in framing and livestock activities and creating other economical projects. Consequently, forest activities have to be managed with sustainable rules for reinforcing the households' resilience against poverty.

5.1.2 Induced Changes in Households' Expenditures Structure: A Mutation in Agricultural and Livestock Practices

Our analysis of forest households' resilience induced by forest policy will focus on changes in their agricultural and livestock practices as a result of increased income (see table 5).

Table 5 emphasises the changes in use of households' income induced by the forest price policy implemented in 1998. The average change in households' total expenditure from 1997 to 2004 is $59 \%$ while the implemented economical projects' investments (activities related to trade, craft activities and NTFPs' transformation) increased of 119\% between 1997 and 2004. The budget shares of agricultural and livestock activities account respectively for $15 \%$ and $18 \%$ in total expenditure in 2004; these activities are important because they are very productive activities more often conducted in rural areas which could reflect the adaptation of forest households to poverty.

Table 5. Households' expenditures' structure changes in PFM sites

\begin{tabular}{|l|r|r|r|}
\hline \multirow{2}{*}{ Types of expenditures } & \multicolumn{2}{|c|}{ Expenditures (FCFA) } & \multirow{2}{*}{ Budget shares (\%) } \\
\cline { 2 - 3 } & $\mathbf{1 9 9 7}$ & \multicolumn{1}{|c|}{$\mathbf{2 0 0 4}$} & \\
\hline Food & $7,366,504$ & $11,474,747$ & 22.91 \\
\hline Health & $2,892,181$ & $4,505,128$ & 8.99 \\
\hline Education & $1,823,997$ & $2,841,226$ & 5.67 \\
\hline Other social expenditures & $8,183,612$ & $12,747,549$ & 25.45 \\
\hline Equipment & $4,827,045$ & $7,519,051$ & 15.01 \\
\hline Livestock breeding & $5,693,807$ & $8,869,199$ & 17.71 \\
\hline Economical Projects & 973,381 & $2,130,750$ & 4.25 \\
\hline Savings & 394,508 & 614,522 & 1.23 \\
\hline Total & $\mathbf{3 2 , 1 5 5 , 0 3 5}$ & $\mathbf{5 0 , 0 8 7 , 6 5 0}$ & $\mathbf{1 0 0 . 0 0}$ \\
\hline
\end{tabular}

Source: Descriptive Analysis of survey data (CIFOR/May-June 2005).

Figure 3 focuses on induced changes in agricultural cultivated areas in PFM sites. The increase in the loggers' compensation induced by the forestry policy has led among them to invest in agricultural and livestock activities including agricultural equipment (plows, carts, donkeys and oxen for animal traction and hoes, etc.) and increases agricultural jobs and livestock heads. This adaptation of forest households will result in an increase in the agricultural areas cultivated by them. 
Several speculations are practiced by loggers including the cultivation of corn, sorghum, millet, peanuts, yam, bean, cotton and rice. the total cultivated area increased by $61 \%$ between 1997 and 2004. The most important crops cultivated by these households are cereals with respective increases in their sown acreage of $146 \%$ for maize, $61 \%$ for sorghum, $28 \%$ for millet, $41 \%$ for groundnuts, $43 \%$ for yams and $57 \%$ for cotton.

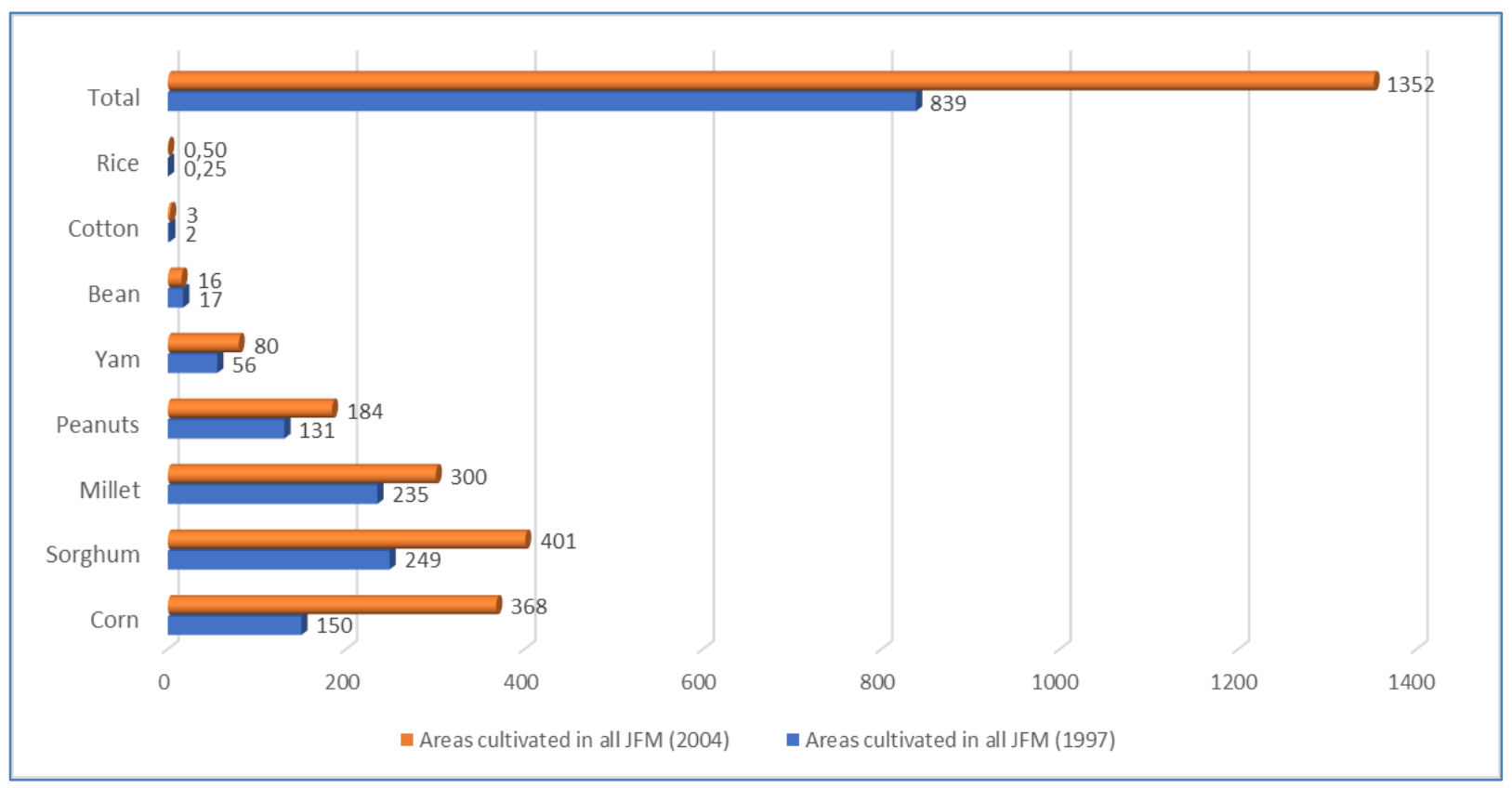

Figure 3. Changes in households' agricultural cultivated areas (ha) in PFM sites

This induced increase in the agricultural areas sown by forest households is accompanied by an increase in their investments in agricultural mechanization (see Table 6).

Table 6. Households' investments in agricultural equipment

\begin{tabular}{|l|r|r|r|r|r|}
\hline \multirow{2}{*}{ Type of equipments } & \multicolumn{2}{|c|}{1997} & \multicolumn{2}{|c|}{2004} & \begin{tabular}{c} 
Variation of \\
\cline { 2 - 5 }
\end{tabular} \\
\cline { 2 - 5 } Number & Expenditures & Number & Expenditures & equipments' number (\%) \\
\hline Plow & 250 & $5,238,500$ & 548 & $3,687,850$ & 119.20 \\
\hline Oxen & 22 & $1,041,018$ & 52 & $3,265,000$ & 136.36 \\
\hline Donkeys & 35 & $1,880,550$ & 90 & $6,770,000$ & 76.74 \\
\hline Daba/Hoes & 43 & 985,044 & 76 & $3,253,000$ & -12.98 \\
\hline Total & 439 & $1,729,660$ & 382 & $1,150,625$ & $\mathbf{4 5 . 5 0}$ \\
\hline
\end{tabular}

Source: Descriptive Analysis of survey data (CIFOR/May-June 2005)

The change in the average total volume of agricultural equipment between 1997 and 2004 was $45 \%$. It should be noted that the number of plows and carts increased by $119 \%$ and $136 \%$ respectively for the same period, while the number of donkeys and bulls has increased by $77 \%$ and $157 \%$ respectively between these two dates. It should be noted that these animals are used for breeding but also for traction in the agricultural practices of forest households. Quite remarkably, the significant decrease in the number of dabas and hoes of these households from 439 to 382, a drop of 13\%, suggests a good trend towards agricultural mechanization.

This change in households' farming practices is supported by an increase in agricultural jobs 
between 1997 and 2004. In fact, the agricultural jobs (labor) used in their farming areas, gets up from 2,875 to 5,403 jobs in 1997 and 2004, be increasing of 88\% (see figure 4).

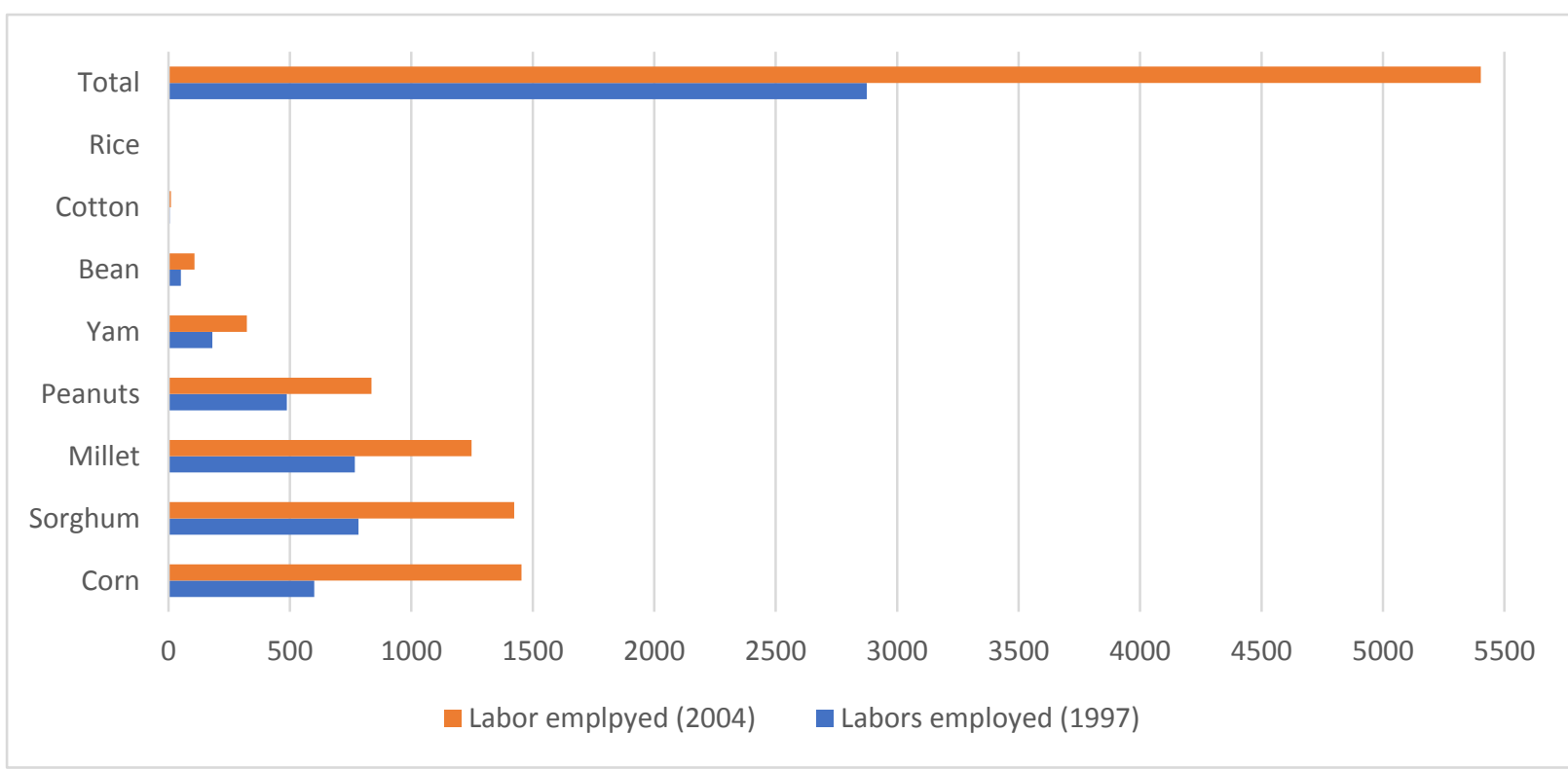

Figure 4. Changes in agricultural labor employed

It's important to notice that the extension of agricultural areas and investments provide agricultural wastes while these wastes contribute for livestock's feeding (see table 7).

Table 7. Changes in livestock breeding in PFM

\begin{tabular}{|l|r|r|r|}
\hline \multirow{2}{*}{ Types of expenditures } & \multicolumn{2}{|c|}{ Expenditures (FCFA) } & Budget shares/Total Budget (\%) \\
\cline { 2 - 3 } & $\mathbf{1 9 9 7}$ & \multicolumn{1}{c|}{$\mathbf{2 0 0 4}$} & \\
\hline Oxen & $2,877,574$ & $4,482,375$ & 8.95 \\
\hline Sheep & $1,579,095$ & $2,459,744$ & 4.91 \\
\hline Goats & 607,563 & 946,397 & 1.89 \\
\hline Poultry & 629,574 & 980,683 & 1.96 \\
\hline Total & $\mathbf{5 , 6 9 3 , 8 0 7}$ & $\mathbf{8 , 8 6 9 , 1 9 9}$ & $\mathbf{1 7 . 7 1}$ \\
\hline
\end{tabular}

Source: Descriptive Analysis of survey data (CIFOR/May-June 2005).

In fact, it is above all the induced increase in the loggers' income and the need to cover up the risks of various consumptions which push the households to invest in the livestock which is a significant productive activity, making increase their total expenditure of livestock from 5,693,807 FCFA in 1997 to 8,869,199 FCFA in 2004, an increase of 56\% over the period studied. The relative importance of these investments in households' total budget in 2004 are respectively accounted for $9 \%$ for oxen, $5 \%$ for sheep, $2 \%$ for goats and $2 \%$ for poultry.

In addition, households constitute savings, thus the observation of the ex-ante and ex-post change of this savings is an important modality that could result from the increase of their income and their coping strategies face to poverty. Generally, poor households save in tontines for precautionary reasons (to deal with possible problems of daily life), but also for reasons of transaction (purchase of a means of transport, establish a fund of trade, open his shop and/or realize a social investment project (weddings, baptisms or funerals), etc.) (Ouedraogo, 2008). They save in the decentralized financial system to access to credit, 
particularly in credit unions. These households' savings volume has increased from 394,508 FCFA in 1997 to 614,522 FCFA in 2004 (see Table 5 above). Furthermore, investment in economical projects such as trade, crafts activities and processing of non-timber forest products has widely increased from 973,381 FCFA in 1997 to 2,130,750 FCFA in 2004, an increase of $119 \%$ (see table 5). Keynes' (1936) work recognized that the level of income has a positive influence on savings.

\subsection{Empirical Investigation of Households'Resilience Face to Poverty in PFM Sites}

In table 8, the three poverty indices for each of the seven forest areas studied are computed (by PFM sites) using respectively the poverty line values of 72,690 FCFA per person per year in 1997 (INSD, 2000) and 82672 FCFA per person per year in 2004 (INSD, 2003).

The average poverty rate over all the PFM sites falls down from 55\% in 1997 to $37.33 \%$ in 2004, while the average poverty gap ${ }^{2}$ in these PFM decreases from $28 \%$ in 1997 to $18 \%$ in 2004. Otherwise, this rate is lower than the national rural poverty rate of Burkina Faso which reaches $52.3 \%$ (INSD, 2003).

Table 8. FGT Poverty indices in PFM sites

\begin{tabular}{|l|c|c|c|c|c|c|}
\hline \multirow{2}{*}{ PFM Sites } & \multicolumn{2}{c|}{ P0* } & \multicolumn{2}{c|}{ P1* } & \multicolumn{2}{c|}{ P2* } \\
\cline { 2 - 7 } & 1997 & 2004 & 1997 & 2004 & 1997 & 2004 \\
\hline Cassou & 84 & 60 & 48 & 33 & 33 & 20 \\
\hline Silly-Pouni-zazwara & 47 & 25 & 18 & 8 & 9 & 3 \\
\hline Sud Ouest sissili & 13 & 6 & 4 & 2 & 2 & 1 \\
\hline Sapoui Bieha & 46 & 15 & 15 & 6 & 7 & 4 \\
\hline Nazinon & 100 & 100 & 85 & 77 & 75 & 65 \\
\hline Nakambé & 50 & 25 & 18 & 7 & 8 & 2 \\
\hline Bougnounou & 79 & 68 & 37 & 18 & 20 & 7 \\
\hline All PFM Sites & $\mathbf{5 5}$ & $\mathbf{3 7}$ & $\mathbf{2 8}$ & $\mathbf{1 7 . 6 3}$ & $\mathbf{1 8}$ & $\mathbf{1 2}$ \\
\hline National rural (INSD; 2000) & 51 & - & 16 & - & 6.8 & - \\
\hline National rural (INSD; 2003) & - & 52.3 & - & 17.90 & - & 6.8 \\
\hline
\end{tabular}

Source: Data analysis on loggers' surveys in Burkina Faso (CIFOR/May-June 2005)

$$
(\mathrm{P} 0 *) \text { Poverty rate }(\%) ; \quad(\mathrm{P} 1 *) \text { Poverty gap }(\%) ;(\mathrm{P} 2 *) \text { Poverty severity }(\%)
$$

Overall, these poverty indices show that fringe forest households' poverty level in PFM sites decreases from 1997 to 2004 as the forest policy of 1998 increases their logging income (TFPs). This result confirms the hypothesis that forest income source contributes to poverty reduction in PFM sites in Burkina Faso, even if the higher poverty severity assumes greater income inequalities among these households. In subtitle 5.1., we allowed the main explanations of these households' resilience face to poverty by demonstrating how the use of induced revenues by the 1998 forest policy permitted forest households to expand their

\footnotetext{
2 Ravallion (1996) gives a very concrete interpretation of the poverty gap, considering it as the minimum cost for eliminating poverty using targeted transfers whose total amount does just equal the sum of all poverty gaps. The severity of poverty is $11.57 \%$ across all PFM sites. This indicator is very high compared to the rural national severity of poverty whose level is $6.8 \%$ (INSD, 2003).
} 
agricultural and livestock activities, to make savings so that to obtain loans from microfinance institutions and to create income-generating activities, particularly through trade, craft activities such as the processing of non-timber forest products, etc. These investments and various expenditures made by the households between 1997 and 2004 constitute in the Béné (2013) approach of resilience's measurement, the costs of adjustment and adaptation developed by households against poverty. This has led to an increase in the average per household non-forest (farm) income from $11 \%$ in 1997 to $16 \%$ in 2004. It is also remarkable to note that households have significantly increased their food, health care and education expenditures, with respective budget shares of 23\%, 9\% and 6\% in 2004 (see Table $5)$.

\section{Concluding Remarks}

The PFM program has been implemented in Burkina since 1986 and the issues of forests' sustainability and their contribution to poverty and income's inequality reduction in PFM sites are recognised as public interest for Burkina Faso. However, there was a need to constantly review the remuneration of loggers, to take into account inflation and persistent poverty in rural areas and more particularly to encourage more loggers among forest fringe households to better appropriate the objectives and purpose of participatory forest management. That's why, since the 1990s, the State has implemented a new price structure for the fuelwood producer and has instituted appropriate economic instruments for environmental policies. Two major components of this 1998 forest policy are the respective increases in loggers' remuneration and Forest Management Fund (FMF). How this policy enables and supports forests' sustainability and forest fringe households' resilience to cope with poverty in PFM sites in Burkina Faso? As concluded by Ouedraogo and Ferrari (2015), the concession for the management of forest areas to village forest management groups and the continuing establishment of new forest management sites justify the relevance and the sustainable management practices that have been adopted. Furthermore, as focused by some authors (Adams, 1994; Reddy and Chakarvarty, 1999; Schlager et al., 1992), changes in property rights emphasizing participatory resource management involving local communities and public agencies, and generating an awareness among the local communities of the ecological and economic impacts of forest degradation, may serve as a starting point to try to reconcile the long-term requirements of forest conservation with the immediate problem of poverty... and a possible way to avoid or, at least, to contribute to the decrease of some ecological inequalities.

We adapt and apply the Béné's (2013) approach of ex-ante and ex-post descriptive analysis of households' income and expenditures to emphasize forests fringe households' resilience against poverty in the PFM sites, mainly by capturing the induced changes by the 1998 forest policy, through expenditures and investments developed by households to cope with poverty.

The main outcomes are as follows. First, the per household's average forest income increases from 1997 to 2004 while its share in total households' average income decreases. Forest sources of income remain the most dominant for these households, which are heavily dependent on forests. For authors like Arnold \& Townson (1998), Kaimowitz (2003) and 
Coulibaly-Lingani \& al. (2009), over two-thirds of Africa's 600 million people obtain a major proportion of their subsistence and some cash income from a large and diverse set of forest products and forest-related activities.

Second, the analysis in changes of FGT poverty indicators in the 7 PFM sites from 1997 to 2004, provide relevant insight on the incidence, the gap and the severity of poverty in these forest areas. The ex-ante and ex-post comparison of both poverty rate and poverty gap observed in all PFM sites, outcomes in a drop in these poverty indicators from 1997 to 2004. Similarly, both poverty rate and poverty gap observed in all PFM sites are lower than those observed in all national rural areas in 2004. That can be interpreted as the fact that logging actually contributes to reduce poverty in PFM sites in Burkina Faso. This decline in the level of poverty in the PFMs is mainly explained by the adaptation behaviour of forest households, who were able to seize the induced increase in their remuneration by the 1998 forest policy, to change and extend their agricultural and breeding practices (purchase of agricultural equipment, purchase of livestock, poultry) and to invest in other economic projects such as artisanal activities, trade and processing of NTFPs. This allowed a relative increase in the average agricultural income per household whose share in the total average income per household increased from $11 \%$ in 1997 to $16 \%$ in 2004 . All of this reflects the ability of these households to cope with increased poverty in rural areas in Burkina Faso. In addition, the households' average total income in the PFM sites increased from 1997 to 2004 by about $65 \%$. This higher rise in the households' average total income in the PFM sites is mainly due to the investments made by these forest households in diversifying their income-generating and productive activities as mentioned above, thus increasing their average agricultural income per household. Otherwise, even if the poverty severity decreases from 1997 to 2004 in PFM sites, its level compared to those observed in national rural areas remains higher suggesting higher income's inequality mong them in PFM sites.

In addition, it is very important to mention the considerable increases induced by the 1998 forest policy, of households' savings and investments (economic projects) from 1997 to 2004. This increase in savings and investments is a great modality and an important expression of the resilience of these households against poverty.

Since the PFM program contributes to poverty alleviation among forests households and strengthen forests' sustainability in PFM sites, the main environmental policy implications should be to update the levels of the instruments of the environmental policy, twenty years after the 1998 forest policy that increased some components of the fuelwood producer price structure.

A potentially interesting extension of the research undergone in that paper would be to investigate on household resilience by analysing their trajectories and by calculating resilience thresholds on the stakes variables. Several authors have used such an approach as Cantoni and Lallau (2010) on Turkana pastoralists confronted with climatic and political uncertainties, or Bidou and Droy (2009) on the temporal construction of vulnerabilities in Madagascar. 


\section{References}

ADAMS, R. Jr., (1994). Non-farm income and inequality in rural Pakistan: A decomposition analysis. Journal of Development Studies, 31(1), 110-133.

https://doi.org/10.1080/00220389408422350

AGIR, (2013). Alliance globale pour la résilience - Sahel et Afrique de l'Ouest. Feuille de route régionale, adoptée le 9 avril.

Arnold, M., \& Townson, I., (1998). Assessing the potential of forest product activities to contribute to rural incomes in Africa. ODI Natural Resource Perspectives 37(November).

Atchoumgaï, B., (2003). L'impact des marchés ruraux de bois de feu dans le village de Korokoro (Cercle de Dioila). Thèse MSc, Institut polytechnique rural de formation et de recherche appliquée (Ipr/Ifra), atibougou, Mali.

Babulo, B., Muys, B., Nega, F., Tollens, E., Nyssen, J., Decker, J., \& Mathijs, E. (2009). The economic contribution of forest resource use to rural livelihoods in Tigray, Northern Ethiopia. Forest Policy and Economics, 11, 109-117. https://doi.org/10.1016/j.forpol.2008.10.007

Barrett, C., \& Constas, M. (2012). Resilience to avoid and escape chronic poverty: Theoretical foundations and measurement principles. November, Draft.

Bene, C., Godfrey, Wood, R., Newsham, A., \& Davies, M. (2012). Resilience: New Utopia or New Tyranny? Reflection about the Potentials and Limits of the Concept of Resilience in Relation to Vulnerability Reduction Programmes, IDS Working Paper, Number 405, september, $61 \mathrm{p}$.

Béné, C. (2013). Towards a Quantifiable Measure of Resilience, IDS Working Paper, Volume 2013, Number 434. Institute of Development Studies, Poverty And Inequality Research Cluster.

Cantoni, C., \& Et Lallau, B., (2010). « La résilience des Turkana », Développement durable et territoires [En ligne], Vol. 1, $\mathrm{n}^{\circ} 2 \mid$ Septembre 2010, mis en ligne le 28 janvier 2016, consulté le 08 décembre 2017. http://journals.openedition.org/developpementdurable/8497

Gausset, Q., Lund, S., Raebild, A., Lompo, D., Ouedraogo, M., et al., (2007). Use of non-wood forest products by local people bordering the "Parc National Kabore Tambi", Burkina Faso. The Journal of Transdisciplinary Environmental Studies, 6, 21.

CIFOR, (2005). Contributing to Africa's Development through Forests Strategy for Engagement in sub-Saharan Africa. Centre for International Forestry Research, Bogor, Indonesia. 35pp.

Coulibaly-Lingani, P., Tigabu, M., Savadogo, P., Oden, P-C, \& Ouadba, J-M, (2009). Determinants of access to forest products in southern Burkina Faso. Forest Policy and Economics, 11, 516-524. https://doi.org/10.1016/j.forpol.2009.06.002

Das, N. (2010). Incidence of forest income on reduction of inequality: Evidence from forest dependent households in milieu of joint forest management. Ecological Economics, 69(8), 
1617-1625. https://doi.org/10.1016/j.ecolecon.2010.03.003

FAO. (1996). Le Burkina Faso: Document de Politique Forestière Nationale, Programme de coopération technique, Rome.

Fisher, M. (2004). Household's welfare and forest dependence in Southern Malawi. Environmental and Development Economics, 9, 135-154.

https://doi.org/10.1017/S1355770X03001219

Fisher, R., J. (1995). Collaborative Management of Forest for Conservation and Development.

Foley, G., Floor, W., Madon, G., Lawali, E. M., Montagne, P., \& Touanao, K. (1997). The Niger household energy project: promoting rural fuelwood markets and village management of natural woodlands. ESMAP/World Bank Technical Paper. Energy series. No. 362. Washington DC: World Bank. https://doi.org/10.1596/0-8213-3918-4

Foley, G., Kerkhof, P., \& Madougou, D. (2002). A review of rural firewood markets strategy in West Africa. African Region Work Paper Series. No. 35. Washington DC: World Bank.

Folke, C., Colding, J., \& Et Berkes, F. (2002). Building Resilience for Adaptive Capacity in Social-Ecological Systems. in Berkes F., Colding, J. et Folke, C. (eds.). Navigating Social-Ecological Systems: Building Resilience for Complexity and Change. Cambridge, uK: Cambridge university press.

Foster, J., Greer, J., \& Thorbecke, E. (1984). A Class of Decomposable Poverty Measures, Econometrica, 52(1), 761-765. https://doi.org/10.2307/1913475

Frankenberger, T., Constas, M., Nelson, S., \& Starr, L. (2014). Current Approaches to resilience programming among nongovernmental organizations, IFPRI, 2020. Conference Paper 7, May.

GRAY, B., (1998). Collaborating: Finding Common Ground for Multiparty Problems. Jossey-Bass, San Francisco, Etats Unis.

Hautdidier, B., Boutinot, L., \& Gautier, D. (2004). La mise en place des marchés ruraux de bois au Mali : un évènement social et territorial. L'Espace géographique, 4, 289-305. https://doi.org/10.3917/eg.334.0289

Hautdidier, B., \& Gautier, D. (2005). What local benefits does the implementation of rural wood markets in Mali generate ? In : African Forests Between Nature and Livelihood Resources : Interdisciplinary Studies in Conservation and Forest Management. Ros-thonen M. A. F., Dietz A. J. (éd.). The Edwin Mellen Press, p.191-220.

INSD, (1996). Résultats des enquêtes prioritaires sur les conditions de vie des ménages de 1994. Ouagadouogou, Burkina Faso.

INSD, (2000). Résultats des enquêtes prioritaires sur les conditions de vie des ménages de 1998. Ouagadouogou, Burkina Faso. 
INSD, (2003). La pauvreté en 2003. Ouagadouogou, Burkina Faso.

Kabore, C. (2004). Bilan des résultats de l'aménagement forestier au Burkina Faso. Ouagadougou, Burkina Faso, Dafor/Mee.

Kaimowitz, D. (2003). Not by bread alone...forests and rural livelihoods in Sub-Saharan Africa. In: Oksanen, T., Pajari, B., Toumasjukka, T. (Eds.), Forests in Poverty Reduction Strategies: Capturing the Potential. European Forest Institute, Joensuu, Finland, pp. 45-63.

Kothari, A., Singh, N., \& Suri, S. (1996). People and protected Areas: Towards Participatory Conservation in India. Sage Publications, New Dehli.

Kristensen, M., \& Balslev, H. (2003). Perceptions, use and availability of woody plants among the Gourounsi in Burkina Faso. Biodiversity and Conservation, 12, 1715-1739. https://doi.org/10.1023/A:1023614816878

Kristensen, M., \& Lykke, A. M. (2003). Informant-based valuation of use and conservation preferences of savanna trees in Burkina Faso. Economic Botany, 52, 203-217.

https://doi.org/10.1663/0013-0001(2003)057[0203:IVOUAC]2.0.CO;2

Kumar, S. (2002). Does participatory in Common pool resource management help the poor? A social cost benefit analysis of participatory forest management (PFM)in Jharkhand, India.World Development, 30(5), 763-782. https://doi.org/10.1016/S0305-750X(02)00004-9

Kumar, S., Saxena, N., Alagh, Y., \& Mitra, K. (2000). India Alleviating Poverty through Forest Development- Evaluation Country Case Study. The World Bank, Washington DC. https://doi.org/10.1596/0-8213-4762-4

Lallau, B., (2011). La résilience, moyen et fin d'un développement durable? Éthique et économique/Ethics and Economics, 8(1).

Lallau, B. (2013). A la recherche des fondements de la résilience, Mémoire d'HDR soutenue le 14 janvier, Université Lille1.

Lallau, B., \& Droy, I. (2014). Qu'est-ce qu'un ménage résilient? Concepts, méthodes, illustrations, in Chataigner JM. (dir), Fragilités et résilience: les nouvelles frontiers de la mondialisation, Chapitre, 9, 149-170.

Lind, J., Sabates-Wheeler, R., \& Kohnstamm, S. (2016). Changes in the drylands of Eastern Africa: implications for resilience-strengthening efforts [Data set]. Brighton: Institute of Development Studies

Mamo, G., Sjaastad, E., \& Vedeld, P. (2007). Economic dependence on forest resources: a case from Dendi District, Ethiopia. Forest Policy and Economics, 9, 916-927.

https://doi.org/10.1016/j.forpol.2006.08.001

Ouedraogo, B. (2002). Éléments économiques pour la gestion de l'offre et de la demande du bois-énergie dans la région de Ouagadougou. Thèse de doctorat unique, université de Ouagadougou/ université Montesquieu- Bordeaux IV, 380 p. 


\section{Macrothink}

Environmental Management and Sustainable Development

ISSN 2164-7682

2018, Vol. 7, No. 1

Ouedraogo, B. (2007), «Filière bois d'énergie burkinabé : structuration des prix et analyse de la répartition des bénéfices », Bois et Forêts des Tropiques, 294(4), 75-88.

Ouedraogo, B. (2009). Aménagement forestier et lutte contre la pauvreté au Burkina Faso, Développement durable et territoires [En ligne], Varia, mis en ligne le 01 septembre 2009, consulté le 26 octobre 2012. URL : http://developpementdurable.revues.org/8215

Ouedraogo, B., \& Ferrari, S. (2015). Incidence of forest activities on poverty: Evidence from forest dependent households in managed forests areas in Burkina Faso. International Journal of Sustainable Development, 18(3). https://doi.org/10.1504/IJSD.2015.070238

Ravallion, M., (1996). Comparaisons de la pauvreté, concepts et méthodes. LSMS document de travail N122. Banque Mondiale, Washington, D.C.

Reddy, S. C. R., \& Chakravarty, S. P. (1999). Forest dependence and income distribution in a subsistence economy: evidence from India. World Development, 27(7), 1141-1149.

https://doi.org/10.1016/S0305-750X(99)00057-1

Ribot J. C. (1995). Le contrôle des forêts locales au Mali : analyse des politiques participatives du point de vue institutionnel. Havard : Havard University, RPTES, Centre for Development Studies.

Ribot, J. C. (1999). Decentralisation, participation and accountability in sahelian forestry: Legal instruments of political-administration control. Africa, 69(1), 23-65.

https://doi.org/10.2307/1161076

Schlager, E., \& Ostrom, E. (1992). Property-rights regimes and natural resources: a conceptual analysis. Land Economics, 68(3), 249-262. https://doi.org/10.2307/3146375

Shackleton, C. M., Shackleton, S. E., Buiten, E., \& Bird, N. (2007). The importance of dry woodlands and forests in rural livelihoods and poverty alleviation in South Africa. Forest Policy and Economics, 9, 558-577. https://doi.org/10.1016/j.forpol.2006.03.004

UNDP, (2014). Human Development Report 2014, Sustaining Human Progress: Reducing Vulnerabilities and Building Resilience, UNDP, July.

Unisdr, (2005). Hyogo Framework for Action 2005-2015, World Conference on Disaster Reduction, 18-22 January, Kobe, Hyogo, Japan.

World Bank, (2001). A revised Forest Strategy for the World Bank group (Draft). The World Bank, Washington DC.

World Bank, (2013). World Development Report 2014, Risk and Opportunity, Managing Risk for Development, Washington DC

Wunder, S. (2001). Poverty alleviation and Tropical forests - What scope for synergies. World development, 29, 1817-1833. https://doi.org/10.1016/S0305-750X(01)00070-5 


\section{Macrothink \\ Environmental Management and Sustainable Development \\ ISSN 2164-7682}

\section{Copyright Disclaimer}

Copyright for this article is retained by the author(s), with first publication rights granted to the journal.

This is an open-access article distributed under the terms and conditions of the Creative Commons Attribution license (http://creativecommons.org/licenses/by/3.0/). 